\title{
The Constitutional Legal Basis of Local Government in the Southeastern Countries of Europe
}

Prof. Ass. Dr Kadri Kryeziu

Vice-Rector and Professor at the University of Prizren "Ukshin Hoti"

\begin{abstract}
In the most general sense, the mission of the local administration or local government is to "ensure governance at the level closest to citizens". Knowing that local government has an important role in the functioning of the state and of law, the local governance in the political system in most countries is primarily seen in its relations with the central government.If the historic point of view is taken into account, the development of local government in Kosovo has a tradition of two centuries. If the Constitution of the Ottoman Empire of 1876 is reviewed, it shows the pyramid of organization of local government in Kosovo, which was in fact inspired from the local government in the West. Speaking about local governance means slotting or reviewing a range of significant phenomena directly related to the destiny of the state. The local government, according to the Constitution of the Republic of Kosovo, represents the public power. It sanctions municipalities as basic administrative and political units.
\end{abstract}

Keywords: constitution, government, local, Kosovo, Europe

\section{Introduction}

Territorial organization of local government according to the Constitution of Kosovo and comparative review of this organization to some constitutions of countries of South-Eastern Europe

The role of local governance in the political system is primarily seen in its relations to the central government. Liberal and democratic observers have presented two bases, upon which these relations have been developed as of the $19^{\text {th }}$ century. First, the local governance is considered as an important factor in encouraging and educating participants in political life and as basis on which services are organized in order to satisfy local needs. Second, the local governance is seen as something rational in administrative point of view, since it ensures the effective performance of public services, where services are necessary under the central administration.

In this regard, the local government is seen as embranchment of central government action (Political Dictionary, 2011). Ahtisaari determined a decentralisation plan that is more detailed than those that are part of each constitution in the region. As far as decentralisation is concerned, there will be a law for that, which does not provide for organization of the state power in three levels, but it will be in two levels, in the central and local government, therefore there will be no regionalisation either in the constitution or in the law. Constitutional tendencies lead to the purpose of decentralisation, which will carry on from political decentralisation into legal decentralisation, with the aim of providing administrative services closer to citizens. The law is the act that materializes the entire specification of the territory of Kosovo, based on the constitution with a special chapter taking into account harmonization and compliance with the European Convention on Local Autonomy. If starting from the historic point of view, the development of local governance in Kosovo has a tradition of two centuries. The tradition 
of local self-governance has existed from of the Ottoman Empire time. As of 1829 and onwards, the local government commenced. There are different periods at different times of the local power.

Kosovo in the Yugoslavian Kingdom had 14-16 districts and over 200 municipalities. In 1945, Kosovo had 500.000 inhabitants, whereas today it has 2 million inhabitants. Now we have a situation that should result from the census in order to define a municipality, then the geographic configuration determines the number that should be: 3000,5000 or 8000 etc. Based on the Constitution of the Republic of Kosovo in Chapter $X$, the local government units in Kosovo are the municipalities and the capital is Prishtina, according to Article 12 of the Constitution of Kosovo. When speaking about the constitutional language for the local government, the Article 12 is also taking into account, because the capital city is also part of the local government as well as chapter 10. The local government in the Constitution of the Republic of Kosovo is stipulated in Article 12, point 1, which states:"Municipalities are the basic territorial unit of local self-governance in the Republic of Kosovo". Whereas point 2 states: "The organization and powers of units of local self-government are provided by law."With regard to relations between the central and local government, the Constitution of Kosovo determines that the municipality is the basic territorial unit and the constitution does not provide for political regional regulation. The local government, according to the Constitution of the Republic of Kosovo, represents the public power. It sanctions municipalities as administrative-political basic units.

The Constitution empowers citizens the right to participate in local government through their representative bodies or directly, meaning that the Mayor of the municipality is elected from the citizens "one citizen one vote", whereas the members of the Assembly are elected indirectly, known as representative democracy. Organization and functioning of local selfgovernment is sanctioned in chapter ten of the Constitution of the Republic of Kosovo, provided in Article 124, paragraph 1 (Constitution of the Republic of Kosovo)

The municipality is the basic local self-government in the Republic of Kosovo. Municipalities have a high extent of selfgovernment and encourage and ensure active participation of all citizens in the decision making process of municipal bodies, Article 13, paragraph 1 and 2: "The capital city of the Republic of Kosovo is Prishtina" and paragraph 2 stated "The status and organization of the capital city is provided by law", which means that Prishtina is also a municipal unit determined by the Constitution, but it has a special status regulated by the law as it is the Capital of Kosovo by the Constitution. Article 12 of the Constitution of Kosovo should be in conjunction with the Chapter X, Article 123, points 1, 2, 3, 4 and Article 124, points $1,2,3,4,5,6$, and 7 . Therefore, the law should be the act that is to specify the issues, whereas the Constitution provides for paths or tracks for further elaboration, taking into account economic and sociologic indicators of culture development, geographic situation and other numerous components that are taken as grounds for conducting territorial organization and local government.

The Constitution of Greece -Likewise in some other European countries, there are two forms of decentralization: territorial and functional decentralization. Currently based on the Constitution of Greece, territorial decentralization was set forth and guarantied in Articles 101 and 102 of the Constitution of Greece, wherein it is stated that administration of local issues is a responsibility of local bodies, that pertains in two levels, the first level territorial decentralization is comprised of municipalities (towns and cities with more than 7.000 citizens). Administrative authorities and urban municipalities that are divided in districts, according to their size, are the Mayor of the municipality, the municipal council; administrative bodies of a smaller rural community are the council of the community and the mayor of the community (Parke \& Kirtman, 2004, p. 383-387).

The Constitution of Turkey - Based on the Constitution of 1982, Article 127 and the amendments of 1995, the administrative units are divided in 79 provinces. Local organization is conducted through 67 large municipalities and districts.

In the Constitution of Bosnia and Hercegovina, Bosnia and Hercegovina is divided into ten cantons, they are: the Una-Sana Canton, the Posavina Canton, the Tuzla Canton, the Zenica-Doboj Canton, the Central Bosnia Canton, the Bosnia Podrinje Canton, the Hercegovina-Neretva Canton, the West Hercegovina Canton, the Sarajevo Canton and the Livno Canton 
(Canton 10). There is no special article on decentralisation. It summarizes the structure and division of responsibilities/competences of federal and local governments: federal, cantonal, joint government, municipal and city government.

The Constitution of Serbia - Based on Article 188 of the Constitution of the Republic of Serbia, the local government is regulated based on territorial units, and they are municipalities, cities and the Belgrade city. The territorial organization of the Republic of Serbia is organized according to the Law on Territorial Organization adopted by the People's Assembly of Serbia on 29 December 2007. Serbia as a territorial unit is comprised of 150 municipalities, 23 cities and the city of Belgrade, as a special unit and from 174 local self-government communities.

Constitution of Cyprus -Administrative division of Cyprus, according to the Constitution of 1997, is divided into main districts, towns, villages and municipalities. The constitution provides for six districts. The district of Nicosia is composed of 56 cities, named in two languages: Greek and Turkish language, whereas the district Kyrenia is composed of 56 cities, named in two languages: Greek and Turkish Language. The district of Famagusta is composed of 90 cities. The District of Larnaca is composed of 3 states and 141 towns and villages.

The Constitution of Albania - According to Article 108, point 1, communes, municipalities and districts are units of local government. The Constitution of Albania has 8 articles on centralization. In the basic principles: Local government is founded upon the basis of the principle of decentralization of power and is exercised according to the principle of local autonomy (Constitution of the Republic of Albania, art XII).In the chapter on local government (sixth section): Determination of local government unit, determination of administration bodies of local government, authorizations and competences of local government.

Constitution of Macedonia - According to Article 114, units of local self-government are municipalities and the city of Skopje, as the capital of Macedonia. The Constitution of Macedonia has 4 articles on decentralization. In basic principles: the fundamental values of constitutional order include the local self-government (Constitution of the Republic of Macedonia, art. VIII).

The Constitution of Montenegro - Article 114, the basic forms of local self-government are municipalities and communes.

Based on the Constitution of Bulgaria, local self-government and local administration are regulated according to Article 135, which is divided in regions, districts, communes, cities and municipalities. Article 136, point 1 states that the municipality is the basic territorial administrative unit, in which local self-government is implemented.

The Constitution of Hungary - According to Article 41, point 1 and 2, states that the territory of the Republic of Hungary is divided into administrative units including the capital city, districts, cities and villages. Point 2: the capital is divided in districts.

The Constitution of Moldavia -based on Article 110, the Republic of Moldavia is structured in regions, districts, cities and villages. Some cities can be declares municipalities based on the law. Administrative division of Moldavia has 40 regions, 6 republican cities and 4 centres (cities), including also the capital Kishinev. The province inhabited from Gagauz, which has an autonomous status, and 5 regions on the left side of the River Nistru (Transnistria acquired a statute as autonomous republic unrecognized by the Government).

\section{Separation and functioning of state powers based on the Constitution of Kosovo in comparative point of view}

As of occurrence of the modern state in political theory and in the constitutional law, the issue of state power separation and functioning has been discussed in horizontal and vertical line. Other conceptual main features that are in the constitutions include the purposeful separation or distribution of three main powers or functions of administration - the executive, legislative and judiciary, identified already by Aristotle and rediscovered by the French lawyer and philosopher Montesquieu. The type, character of state bodies, relations among them, was a topic of scientific, political and constitutional discussions. Early on, Montesquieu emphasized that there is no freedom if the three primary powers are not divided 
(Montesquieu, 2002).Only the people may build the power, if we preserve the notions of constitution, its initial meaning and its political sustainability ( Duhamel, 1993, p. 20)

The principle of separation of powers in legislative, executive and judicial is the most important principle and element of the rule of law state. The main purpose of introducing this principle in legal theory and practice was the demand for better recognition and guarantee of individual's rights and freedoms (Zaganjori, 2002, p. 97).

As known from the modern general theory of state and law, one of overall characteristics of state is the state power, or the apparatus through which it implements its political will. The state power is manifested and expressed in three basic forms, such as: constitutional and legislative power, executive - administrative power and judicial power (Elezi, 2007, p. 91).

The state power, based on the Constitution of Kosovo, is primarily manifested and expressed in three basic forms, in constitutional and legislative power, executive - administrative power and judiciary. In the basic provisions of the Constitution of the Republic of Kosovo, the separation of powers is sanctioned under Article 4, point 1, 2, 3 and 4. In Article 4, point 1 it is stated that: "Kosovo is a democratic Republic based on the principle of separation of powers and the checks and balances among them as provided in this Constitution"; point 2 "The Assembly of the Republic of Kosovo exercises the legislative power"; point 3 ( The Constitution of The Republic of Kosovo, cl.2, 3)

"The President of the Republic of Kosovo represents the unity of the people". The President of the Republic of Kosovo is the legitimate representative of the country, internally and externally, and is the guarantor of the democratic functioning of the institutions of the Republic of Kosovo, as provided in this Constitution"; point 4 "The Government of the Republic of Kosovo is responsible for implementation of laws and state policies and is subject to parliamentarian control" and point 5 "The judicial power is unique and independent and is exercised by courts" ( The Constitution of The Republic of Kosovo, cl. 4)

According to the Constitution of Greece, the state power is sanctioned based on Article 26, point 1, 2, 3. The legislative power shall be exercised by the assembly and by the speaker of the assembly, that is different from the exercise of legislative power in the Constitution of Kosovo, wherein the speaker of the parliament is not underlined; the executive power shall be exercised by the president and the. There is also a substantial distinction to the Constitution of Kosovo, in which it was sanctioned that the executive power shall be exercised by the government; and the judicial power shall be exercised by the courts, which render judgments in the name of the Greek People (The Constitution of the Republic of Greece).

The Constitution of Turkey - the state power in Turkey functions based on the principle of separation of powers and is dividing according to Articles 7, 8 and 9 of the Constitution of the Republic of Turkey. The Legislative power belongs to the Grand National Assembly of Turkey, which is composed of parties wining $10 \%$ of ballots. The assembly is a single chamber, composed of 550 members with a 5 year mandate and it acts on behalf of the Turkish nation. There are no divisions in exercising the legislative power, but in composition of the MPs, because Kosovo has 120 MPs, whereas the National Assembly of Turkey has $550 \mathrm{MPs}$, and the second difference is with regard to the election. In Kosovo, it is $5 \%$, whereas in Turkey $10 \%$ in order for the political parties to get seats in the parliament.

This power cannot be delegated. From the historical point of view, some distinguished personalities of the Albanian nation were stakeholders and part of the legislation as of September 1908, after the promulgation of the Law on Parliamentary Elections, in September 1908. On 17 December of the same year, the Young Turk Parliament was established. In the parliament 26 members of the parliament were elected from the provinces inhabited by the Albanians, among whom there were Ismail Qemali, Nexhip Draga, Hasan Prishtina, Shahin Kolonja, etc. Within the Parliament an opposition group was established from the members who had liberal and anti-centralist views, led by Ismail Qemali (Bicaj, p.164).

According to Article 8 of the Constitution of the Republic of Turkey, the executive power shall be exercised by the President of the Republic, who is the head of the state and is elected by a majority of at least two thirds of the Grand National Turkish Assembly, known as Meçlis, for a mandate of seven years, but only for a single mandate. In order for a candidate to be 
qualified for such a function shall be a Turkish citizen and shall be over 40 years old, which implies a fundamental distinction, since the President of Kosovo does not possess these executive competences exercised by the Turkish President.

The Turkish President shall chair the National Security Council and perform the function of the Chief Commander. During the war times, the Chief of General Headquarters acts as the Chief Commander on behalf of the President. The president has the authority to promulgate or return laws to the parliament for review, to call public referendums, to call the new parliamentary elections, to nominate the prime minister or to accept his/her resignation, to appoint or dismiss ministers, to ratify and publish international agreements, etc.

The executive power is exercised by the President and the Council of Ministers, chaired by a Prime Minister. The Prime Minister is appointed by the President from the members of the Grand National Assembly of Turkey and he/she appoints ministers, prior to the general elections.

According to Article 9 of the Constitution of the Republic of Turkey, the judicial power is exercised by the independent courts in the name of the Turkish People. If comparisons take place, it comes out that the judiciary is exercised by the courts, in both states, based on their constitutions, either the one of Kosovo or of Turkey; however, in the Turkish Constitution there are several types of courts, which are not foreseen in the Kosovo Constitution, i.e. the Military Court. Moreover, it is provided for that Turkey has a unified legal system of civil and military courts, each of that with the court of appeals as a final instance for reviewing decision and trials made by the courts of justice. The Constitution of 1982, provided for the establishment of courts on state security in dealing with criminal offences against domestic and external security of the state (Constitution of the Republic of Turkey).

The state power in Bosnia and Herzegovina based on the Constitution of Bosnia and Herzegovina, respectively Article 4, 5 and 6 , it also separated in legislative power that is exercised by the Parliamentary Assembly, composed of the Chamber of Representatives and the Chamber of Peoples. The distinction here is on the fact that Kosovo has a constitutional and legislative institution, whereas based on the Constitution of Bosnia and Herzegovina, the legislative power is exercised by the Parliamentary Assembly, which comprises of two chambers.

The executive power is exercised by the Presidency and the Council of Ministers, whereas the judicial power is exercised by the regular courts and the Constitutional Court (Constitution of Bosnia and Hercegovina).

Based on the Constitution of Serbia, Article 4, there is separation of legislative, executive and judicial powers. The relation between the three branches of the state power, which is based on their reciprocal check and balance. The legislative power, based on Article 98 of the Constitution of Serbia, is exercised by the National Assembly; the executive power is exercised by the president of the republic and the government that is the main institution in charge of the executive power; whereas the judicial power is exercised by the courts. Compared to the Constitution of the Republic Kosovo, there is no fundamental distinction in the internal composition of the parliament and its structure (Constitution of the Republic of Serbia, art. XCIV ).

Based on the Constitution of Cyprus, the state power is separated in legislative power, which is provided under Article 61, exercised by the chamber of representatives in all matters, except for special cases by the chambers of municipalities. That is to say that there are distinctions in composition and structure of the legislative body, then, there are also functional distinctions. The executive power is exercised by the president of the republic, the vice president and the council of ministers, with separated powers (Constitution of Cyprus, art. LXI).

The legislative power is exercised by the single chamber parliament; the Chamber of Representatives comprises of 80 members, elected directly by the people, with a mandate of 5 years, 56 from the Greek community and 24 from the Turkish community. The executive power is exercised by a president and a vice president, elected from both communities, together with the council of ministers, 7 Greek ministers and 3 Turkish ministers, appointed by the president and the vice president. The president of the state is elected directly by the people for a mandate of 5 years (Lidia \& Mushat, p. 123). 
Based on the Constitution of Albania, Article 7, the state power is separated and balanced among the legislative, executive and judicial power. The legislative power is exercised by the parliament, the executive one by the government, respectively the Council of Ministers and the judiciary by the courts (Constitution of the Republic of Albania, art. VII).

The state power in the Republic of Macedonia, based on the constitution, is separated in legislative power exercised by the parliament, executive power exercised by the government and the judiciary by the courts according to Article XCVIII (Constitution of the Republic of Macedonia, XCVIII).

By the Constitution of Montenegro, the state power is separated into legislative, executive and judiciary. The separation of powers is made according to Article XI of the Constitution of the Republic of Montenegro (Constitution of the Republic of Montenegro, art XI).

In the Republic of Macedonia, the state power is separated based on Article LXII. The legislative power is exercised by the National Assembly, whereas the executive power by the Council of Ministers, according to Article CV of the Constitution of the Republic, whereas the judicial power is exercised by the courts, as per Article CXVII (Constitution of the Republic of Bulgaria, art. CXVII).

The new Constitution of Hungary is combined with a range of basic laws that were adopted at the end of 2011, excluded all the possibilities of control by the government and the ruling party. The power of the Constitutional Court was put in shadow, and it was requested a regulation on religion, by reducing the number of registered religious sects to 14 , wherein no other religion is included, apart from Christianity and Jewish. The Constitution of Hungary sanctions the separation of power based on Article 19. The Parliament is the legislative body; the executive power is exercised by the government, according to Article XXXIII, whereas the judicial power is exercised by the courts based on Article 45 of the Constitution of the Republic of Hungary (Constitution of the Republic of Hungary, art. XXXIII, XLV).

Also in the Republic of Moldavia, the power is separated, but balanced. The separation of power is sanctioned in general provision, based on Article VI, wherein it is stated that the power is separated in legislative, executive and judiciary. The legislative power is exercised by the parliament, the executive power by the government, whereas the judicial power by the courts, based on Article CXIV of the Constitution of the Republic of Moldavia (Constitution of the Republic of Moldavia, art. CXIV).

\section{Conclusion}

This chapter includes comparative models of the constitutions of 11 countries of South Eastern Europe, in the scope of structure, content, democratic orientation of political regime sanctioned based on the constitution of countries of South Eastern Europe and Kosovo; forms of state government, based on the above-mentioned constitutions; territorial organization of local government, according to the Constitution of Kosovo and some constitutions of the countries of South Eastern Europe and separation and functioning of state powers.

My conclusion in comparative structural aspect of the Constitution of the Republic of Kosovo, in relation to these 11 constitutions of the countries of South Eastern Europe, provides that any effort to understand or compare constitutions today was not possible without any historical background and the political and social context in which basic principles contained in the document would be set, as mentioned above. Distinctions and similarities could be surprising.

Political regimes sanctioned by all constitutions that are subject of my review, all countries or states of democratic regime, which implies that as an expression of citizen will through their legitimate representatives, determined the form of regime and afterwards it comes out that the forms of state government are sanctioned in the constitution as parliamentary republics, some of them as presidential republics and some as semi-presidential republics; it comes out that the state power is divided and balanced, whereas the organization of local administration appears to be distinctive in all countries in which these constitutions were sanctioned. 


\section{Literature}

[1] Bicaj, R. (2002). Enciklopedia Part I. Tirana, Albania

[2] Duhamel. O. (1993) Constitutional Law - Democracies. Paris

[3] Elezi. Z. (2007). Constitutional Law (summary of university books). Tetove: .

[4] Kortman. K. (2002). Mbi frymën e ligjeve. Tiranë

[5] Macmillan. A., (2011). Political dictionary. New York City

[6] Mushat. L\& S. (2005). Geographic Encyclopaedia of Europe.

[7] Prakke. L \& Kortman. C. (2004). GeogrConstitutional Law of 15 EU member statesaphic Encyclopaedia of Europe

[8] Zaganjori. Xh. (2002). Democracy and the rule of law. Tiranë

[9] The Constitution of Republic of Kosovo. Art I, cl. 1

[10] The Constitution of Republic of Kosovo. Art CXXIV parag.1

[11] The Constitution of Republic of Kosovo. Art CXXIII, 1,2,3,4

[12] The Constitution of Republic of Kosovo. Art XIII, cl, 1,2,3,4,5,6,7

[13] The Constitution of Turkey, art. VII, VIII, XIV

[14] The Constitution of Bosnia and Herzegovina, art. IV, V, VI

[15] The Constitution of Serbia, art. IV, XCVIII, CLXXXVIII

[16] The Constitution of Albania, art. CVIII, cl. 1, 7

[17] The Constitution of the Republic of Albania, art. XIII

[18] The Constitution of Macedonia, art. CXIV art. IV

[19] The Constitution of Montenegro, art. CXIV

[20] The Constitution of Hungary, art. XLI, Cl. 1 and 2

[21] The Constitution of Moldavia, art. CX cl. 1

[22] The Constitution of Cyprus, art. LXI 